DoLBy, D. E. (1955). J. gen. Microbiol. 12, 406-418

\title{
The Effect of Enzyme Inhibitors on the Multiplication of T 2 Bacteriophage
}

\author{
BY D. E. DOLBY \\ Lister Institute of Preventive Medicine, Elstree, Hertfordshire
}

\begin{abstract}
SUMMARY: Screening tests on the inhibition of growth of phage $\mathbf{T} 2 \mathrm{r}^{+}$and of its host, Escherichia coli strain B, by a number of enzyme inhibitors, showed that only arsenite, borate and cyanide inhibited the phage at concentrations which were without effect on the phage alone, on its adsorption to bacteria, or on bacterial growth. In single-step experiments, the inhibitory effect of arsenite and cyanide on phage multiplication was maintained for several hours, whereas borate merely lengthened the latent period by a few minutes without decreasing the final titre. Arsenite was still effective as an inhibitor when added half way through the latent period.
\end{abstract}

Work on the effect of inhibitors on the multiplication of bacterial viruses has been carried out almost since the discovery of bacteriophage; but it is only with the more recent interest in chemotherapy and antibiotics, and with the possibility that results with bacterial viruses might be applicable to other viruses, that it has become extensive. Compounds of many kinds have proved to inhibit virus multiplication but, with few exceptions, their mode of action is obscure. This is perhaps because the compounds were used empirically to prevent virus growth, rather than for studying the inhibitory process. The work of Cohen (Cohen, 1951; Cohen \& Roth, 1953; Scott \& Cohen, 1953 $a, b$ ) on the metabolic processes of Escherichia coli and on the isolation of the enzymes concerned has thrown more light on the mechanisms involved in phage production; but inhibition experiments can play their part in elucidating the process. The results presented in this paper show that substances known to be enzyme inhibitors can inhibit phage production at concentrations which are without effect on bacterial growth, and that the type of inhibition may vary according to the enzymic reaction affected.

\section{METHODS}

Media. The liquid medium used (GTP broth) contained $2 \%(\mathrm{w} / \mathrm{v})$ Difco Bacto Tryptose; $0.2 \%(\mathrm{w} / \mathrm{v})$ glucose; $0.5 \%(\mathrm{w} / \mathrm{v}) \mathrm{NaCl}$; and $0.01 \mathrm{M}$-phosphate buffer (pH 7·2).

Both phage and bacteria were diluted in a medium (phosphate saline) containing: $0.08 \mathrm{M}-\mathrm{NaCl} ; 0.01 \mathrm{M}$-phosphate buffer $(\mathrm{pH} \mathrm{7.2)} ; 0.005 \mathrm{M}-$ magnesium chloride; $0 \cdot 1 \%(\mathrm{w} / \mathrm{v})$ gelatin.

Bacteriophages. Escherichia coli strain B, and the T series of bacteriophages were originally obtained from the late Dr W. J. Elford, F.R.S. The E. coli strain B, was subcultured fortnightly on nutrient agar slopes with periodical plating out to test purity of the stock, and isolation of single colonies which 
were then tested to ensure that they had the same sensitivity to the $T$ phages as the parent strain.

Concentrated bacteriophage preparations were obtained by the method of Swanstrom \& Adams (1951), the final product being dialysed against M/15 phosphate buffer $\left(\mathrm{pH} \mathrm{7 \cdot 2)}\right.$. Titres were usually in the range $1-5 \times 10^{11}$ particles/ $\mathrm{ml}$. In some cases GTP broth lysates of coliphage T $2 \mathrm{r}^{+}$were concentrated by a modification of the method of Herriott \& Barlow (1952): the lysate was mixed with acid- and alkali-washed Stellafilt (Grade SSS. Paterson Engineering Co. Ltd., 83 Kingsway, London), filtered, cooled to $0^{\circ}$ and the $\mathrm{pH}$ brought to 3.9-4.0 with $\mathrm{N}-\mathrm{HCl}$. The precipitate was then centrifuged down at $0^{\circ}$, suspended in a small volume of saline at $0^{\circ}$ and dissolved by addition of the minimum quantity of $\mathrm{M}-\mathrm{NaHCO}_{3}$. After a preliminary titration the product was diluted to a titre of $5 \times 10^{11}$ with phosphate saline.

In all bacteriophage preparations sterility was maintained with a crystal of thymol.

Bacteriophage counts. These were made in duplicate by the plaque-counting method of Hershey, Kalmanson \& Bronfenbrenner (1943), using digest broth solidified with $1.5 \%(\mathrm{w} / \mathrm{v})$ agar for the base and with $0.75 \%(\mathrm{w} / \mathrm{v})$ agar for the upper layer.

Bacterial counts. Bacterial growth was followed by viable count or by nephelometer (Evans Electroselenium Ltd.) calibrated against total counts of $\log$ phase cultures of Escherichia coli strain B. The viable count was always measured when growth was occurring in the presence of an inhibitor.

Inhibitor solutions. Inhibitors were usually dissolved in saline; but 8-hydroxyquinoline was dissolved in ethanol and the solution diluted with saline to below $1 \%(\mathrm{v} / \mathrm{v})$ ethanol. Sulphanilamide and $2^{\prime}: 4$-dinitrophenol were dissolved in the minimum of $\mathrm{N}-\mathrm{NaOH}$, and arsenite was used either as the salt or by dissolving $\mathrm{As}_{2} \mathrm{O}_{3}$ in the minimum of $\mathrm{N}-\mathrm{NaOH}$. All solutions were brought to $\mathrm{pH} 7$ before use.

\section{SCREENING TESTS}

Preliminary experiments were made with a number of substances known to inhibit a range of enzyme reactions, to discover those which would decrease phage yield at levels which were without effect on bacterial growth. An inhibitor which does not completely suppress phage multiplication may (1) increase the length of the latent period; (2) increase the length of the rise period; (3) decrease the final titre; or may produce all three effects in combination. The criterion of inhibition has usually been decrease in final titre, but changes in latent period or increase in titre may be more sensitive indicators, since partial inhibition of an enzymic process essential to phage production might decrease the rate of phage multiplication without decreasing the number of phage particles finally produced. Comparison between the titres of control suspensions of phage and bacteria and those containing inhibitors shortly after the end of the normal latent period will show if any of these types of inhibition is occurring, and also has the advantage that it does not entail the large amount of plating needed to follow growth curves. Experiment showed 
that when a log-phase culture of Escherichia coli strain B, in GTP broth $\left(5 \times 10^{7}\right.$ organisms $/ \mathrm{ml}$.) was infected with an equal number of $\mathrm{T} 2 \mathrm{r}^{+}$particles and titrated at intervals by pipetting samples into phosphate saline at $0^{\circ}$ to prevent further multiplication, the phage titre began to rise at 18-19 min. and had increased five- to tenfold by 20-21 min. This system was therefore made the basis of the inhibition test.

A series of tubes containing different concentrations of freshly prepared inhibitor solution ( $1 \mathrm{ml}$.) were brought to $37^{\circ}$ in a water-bath and to each at $1 \mathrm{~min}$. intervals added $10 \mathrm{ml}$. of a log-phase culture of Escherichia coli strain $\mathrm{B}$, in GTP broth, containing $5 \times 10^{7}$ organisms $/ \mathrm{ml}$. as measured by nephelometer. When culture and inhibitor in each tube had been in contact exactly $10 \mathrm{~min} .5 \times 10^{8} \mathrm{~T}_{2} \mathrm{r}^{+}$particles in $0.1 \mathrm{ml}$. broth were added to it. After $20 \mathrm{~min}$. incubation $0.1 \mathrm{ml}$. was withdrawn into $20 \mathrm{ml}$. phosphate saline at $0^{\circ}$ to stop the phage multiplication and, after further dilution, assayed for phage. A duplicate set of tubes containing only inhibitor and bacterial culture was set up at the same time, incubated for 70-75 min. and then plated to determine the effect of the inhibitors on bacterial growth rate. Controls containing saline in place of inhibitor were included, and the initial titre of phage and viable bacteria determined on these. Experiments in which the phage multiplication in the control at $20 \mathrm{~min}$., or the bacterial multiplication after $70 \mathrm{~min}$., was less than fivefold were rejected. The results of a typical experiment are given in Table 1. The degree of inhibition of phage and of bacterial multiplication is expressed as an inhibition index $=$

$$
\frac{\log \text { (final titre in presence of inhibitor/initial titre) }}{\log \text { (final titre in control/initial titre) }} .
$$

Complete inhibition, or decrease of the initial titre, thus gives an index of 0 ; complete absence of inhibition gives an index of 1 (Table 1 , cols. 4 and 6). A completely differential inhibitor of phage multiplication should decrease the inhibition index for phage below unity at a concentration that does not affect the index for $E$. coli strain B. However, substances which gave a phage index of 0.5 or less and a bacterial index of 0.9 or more have been regarded as differential inhibitors.

Twelve of the substances tested were not differential inhibitors (Table 2) and four of them were (Table 3 ). The compounds were tested at concentrations giving phage indexes from 0 to 1 in all cases except sodium cacodylate, which did not inhibit at $0 \cdot 1 \mathrm{M}$, and sodium fluoroacetate, which did not inhibit at $100 \mu \mathrm{g} . / \mathrm{ml}$. $\left(1 \times 10^{-6} \mathrm{M}\right)$, the highest concentration tested. With the same exceptions, all compounds were tested at concentrations giving bacterial inhibition indexes from less than $\mathbf{0 . 5}$ to $\mathbf{1}$. These results modify some of those presented by Czekalowski \& Dolby (1949).

\section{Effect of inhibitors on free phage and on adsorption of phage}

Dilutions of phage in GTP broth containing about $5 \times 10^{7} \mathrm{~T} 2 \mathrm{r}^{+}$particles $/ \mathrm{ml}$. were incubated with each of the four active inhibitors for $4 \mathrm{hr}$. at $37^{\circ}$ to determine whether they had any action on the phage alone (Table 4). Arsenite, 
borate and cyanide were without effect at concentrations higher than those used in inhibition experiments. Proflavine inactivated coliphage $\mathrm{T} 2 \mathrm{r}^{+}$at $5 \times 10^{-5} \mathrm{M}$. This is a lower inhibitory concentration than that recorded by Foster (1948), but is in accord with the results of Hedén (1951). In other experiments there was considerable destruction of coliphage $\mathbf{T} 2 \mathbf{r}^{+}$even at

Table 1. Effect of various concentrations of compounds on the multiplication of bacteriophage and bacteria

\begin{tabular}{|c|c|c|c|c|c|}
\hline \multirow[b]{2}{*}{ Compound } & \multirow[b]{2}{*}{$\begin{array}{c}\text { Final } \\
\text { concentration } \\
\left(\mathbf{M} \times 10^{-3}\right)\end{array}$} & \multicolumn{2}{|c|}{ Bacteriophage } & \multicolumn{2}{|c|}{ Bacteria } \\
\hline & & $\begin{array}{c}\text { Titre } \\
\text { after } \\
20 \mathrm{~min} . \\
\left(\times 10^{8}\right)\end{array}$ & $\begin{array}{c}\text { Inhibition } \\
\text { index* }\end{array}$ & $\begin{array}{l}\text { Viable } \\
\text { count after } \\
75 \text { min. } \\
\left(\times 10^{6}\right)\end{array}$ & $\begin{array}{c}\text { Inhibition } \\
\text { index* }\end{array}$ \\
\hline Saline & 一 & 297 & - & 353 & 一 \\
\hline Proflavine & $\begin{array}{l}0.001 \\
0.0025 \\
0.005 \\
0.01 \\
0.02\end{array}$ & $\begin{array}{r}248 \\
143 \\
63 \\
8 \\
4\end{array}$ & $\begin{array}{l}0 \cdot 91 \\
0 \cdot 63 \\
0 \cdot 21 \\
0 \\
0\end{array}$ & $\begin{array}{l}366 \\
345 \\
336 \\
271 \\
213\end{array}$ & $\begin{array}{l}1.02 \\
0.99 \\
0.97 \\
0.85 \\
0.70\end{array}$ \\
\hline Zinc acetate & $\begin{array}{l}0 \cdot 05 \\
0 \cdot 10 \\
0 \cdot 20 \\
\mathbf{0} \cdot \mathbf{5 0}\end{array}$ & $\begin{array}{r}353 \\
365 \\
241 \\
14\end{array}$ & $\begin{array}{l}1 \cdot 09 \\
1 \cdot 11 \\
0 \cdot 89 \\
0\end{array}$ & $\begin{array}{l}390 \\
370 \\
355 \\
196\end{array}$ & $\begin{array}{l}1 \cdot 06 \\
1 \cdot 03 \\
1 \cdot 00 \\
0 \cdot 66\end{array}$ \\
\hline
\end{tabular}

Ten $\mathrm{ml}$. log phase culture of Escherichia coli strain B in GTP broth added to duplicate tubes of $1 \mathrm{ml}$. inhibitor at $-10 \mathrm{~min}$. Viable count on saline control at $-2 \mathrm{~min} .: 64 \times 10^{6}$ organisms $/ \mathrm{ml}$. $0.1 \mathrm{ml}$. T $2 \mathrm{r}^{+}$dilution added to one of each pair of tubes at $0 \mathrm{~min}$. to give phage concentration: $43 \times 10^{8}$ particles $/ \mathrm{ml}$.

* Inhibition index $=\frac{\log (\text { final titre in presence of inhibitor/initial titre) }}{\log (\text { final titre in control/initial titre) }}$

$5 \times 10^{-6} \mathrm{M}$-proflavine and some evidence that destruction was less when the mixture was incubated in the dark. This apparent photo-inactivation may be responsible for the discrepancies between the results of different workers. The adsorption of phage to Escherichia coli strain B was not affected by the presence of arsenite $\left(2 \times 10^{-3} \mathrm{M}\right)$, borate $\left(7 \times 10^{-3} \mathrm{M}\right)$, cyanide $\left(0 \cdot 8 \times 10^{-3} \mathrm{M}\right)$, or proflavine $\left(0.01 \times 10^{-3} \mathrm{M}\right)$.

\section{THE COURSE OF PHAGE MULTIPLICATION IN THE PRESENCE OF INHIBITORS}

The effects of arsenite, borate and cyanide on phage multiplication were studied in greater detail by single-step growth curves in the presence of these inhibitors. For this purpose stable suspensions of phage + bacteria were prepared in two ways:

(a) By the method of Benzer (1952), in which phage is adsorbed on to washed bacteria in a non-nutrient medium. A log phase culture in GTP broth of Escherichia coli strain B $\left(1 \times 10^{8}\right.$ organisms $/ \mathrm{ml}$.) was centrifuged at 3000 r.p.m. for 20 min., washed twice on the centrifuge with phosphate saline, 
Table 2. Inhibition indexes of compounds which did not show differential inhibition

\begin{tabular}{|c|c|c|c|c|}
\hline & & & Average inhi & tion index \\
\hline Compound & $\left(\mathrm{M} \times 10^{-3}\right)$ & experiments & Bacteriophage & Bacteria \\
\hline Azide, $\mathrm{Na}$ & $0 \cdot 9$ & 2 & 0 & $0 \cdot 10$ \\
\hline & $\mathbf{0 \cdot 6}$ & $\mathbf{3}$ & $0 \cdot 15$ & 0.50 \\
\hline & $0 \cdot 4$ & 2 & $0 \cdot 63$ & 0.96 \\
\hline & $0 \cdot 3$ & 4 & 0.90 & $1 \cdot 03$ \\
\hline & $0 \cdot 2$ & 3 & 0.98 & 0.96 \\
\hline Cacodylate, Na & 100 & $\mathbf{1}$ & $0 \cdot 98$ & $1 \cdot 14$ \\
\hline 4:6-Dimethoxytoluquinone & $\mathbf{2 \cdot 5}$ & 1 & 0 & $\mathbf{0} \cdot \mathbf{3 0}$ \\
\hline & $1 \cdot 0$ & 2 & $\mathbf{0}$ & $0 \cdot 64$ \\
\hline & 0.5 & 1 & $1 \cdot 02$ & $0 \cdot 86$ \\
\hline & $0 \cdot 25$ & 1 & c. $1 \cdot 6$ & $1 \cdot 08$ \\
\hline 2:4-Dinitrophenol & $1 \cdot 0$ & 1 & $\mathbf{0}$ & $0 \cdot 46$ \\
\hline & $\mathbf{0 \cdot 3}$ & 2 & 0.5 & $0 \cdot 73$ \\
\hline & $0 \cdot 2$ & 3 & 0.44 & $0 \cdot 91$ \\
\hline & $0 \cdot 15$ & 2 & $\mathbf{1} \cdot \mathbf{0 0}$ & 0.90 \\
\hline Fluoride, $\mathrm{Na}$ & 50 & 1 & 0 & $0 \cdot 34$ \\
\hline & 25 & 1 & $\mathbf{0}$ & $0 \cdot 61$ \\
\hline & $12 \cdot 5$ & 1 & 0.79 & 0.94 \\
\hline & $6 \cdot 2$ & 1 & $1 \cdot 02$ & $1 \cdot 00$ \\
\hline Fluoroacetate, Na & 0.001 & $\mathbf{3}$ & $1 \cdot 05$ & $0 \cdot 96$ \\
\hline 8-Hydroxyquinoline & $0 \cdot 05$ & 1 & 0 & $0 \cdot 66$ \\
\hline & 0.03 & 2 & $0 \cdot 28$ & $0 \cdot 83$ \\
\hline & 0.02 & 2 & $0 \cdot 79$ & $0 \cdot 91$ \\
\hline & 0.015 & 2 & $0 \cdot 89$ & $1 \cdot 00$ \\
\hline & 0.010 & 3 & $0 \cdot 88$ & $1 \cdot 05$ \\
\hline & $0 \cdot 0075$ & 2 & 0.96 & $1 \cdot 04$ \\
\hline Monoiodoacetate, $\mathrm{Na}$ & $0 \cdot 10$ & 1 & $\mathbf{0}$ & $0 \cdot 24$ \\
\hline & $0 \cdot 05$ & 2 & $0 \cdot 03$ & 0.77 \\
\hline & 0.025 & 2 & $0 \cdot 61$ & 0.93 \\
\hline & $0: 01$ & 2 & 0.98 & $0 \cdot 88$ \\
\hline & 0.005 & 1 & $1 \cdot 01$ & 0.99 \\
\hline Sulphanilamide & 20 & $\mathbf{1}$ & $\mathbf{0}$ & $0 \cdot 09$ \\
\hline 2 & 15 & 2 & $\mathbf{0} \cdot 53$ & 0.90 \\
\hline & 10 & 2 & $0 \cdot 84$ & $1 \cdot 10$ \\
\hline & 5 & 1 & $1 \cdot 00$ & 0.96 \\
\hline Uranyl acetate & $4 \cdot 0$ & 1 & 0 & 0 \\
\hline & $\mathbf{2} \cdot 0$ & 2 & $0 \cdot 45$ & $0 \cdot 67$ \\
\hline & $1 \cdot 0$ & 2 & $\mathbf{0} \cdot \mathbf{8 1}$ & $0 \cdot 84$ \\
\hline . & 0.5 & 2 & $0 \cdot 99$ & $1 \cdot 04$ \\
\hline Urethane & 300 & 1 & 0 & $0 \cdot 08$ \\
\hline & 150 & 1 & $0 \cdot 19$ & $0 \cdot 80$ \\
\hline & 75 & 1 & $0 \cdot 5$ & 0.97 \\
\hline Zinc acetate & 0.5 & 1 & 0 & $0 \cdot 66$ \\
\hline & $0 \cdot 4$ & 1 & $0 \cdot 14$ & $0 \cdot 72$ \\
\hline & 0.2 & 1 & $0 \cdot 89$ & $1 \cdot 00$ \\
\hline & $0 \cdot 1$ & 2 & $1 \cdot 00$ & $1 \cdot 01$ \\
\hline
\end{tabular}


resuspended in phosphate saline at about $1 \times 10^{9}$ organisms $/ \mathrm{ml}$. and aerated for $1 \mathrm{hr}$. to remove intracellular nutrients. A viable count was made and T $2 \mathrm{r}^{+}$particles added to a multiplicity of infection of 3-5. After adsorption at $37^{\circ}$ for $10 \mathrm{~min}$. the bacteria with adsorbed phage were centrifuged,

Table 3. Inhibition indexes of compounds showing differential inhibition

\begin{tabular}{|c|c|c|c|c|}
\hline \multirow[b]{2}{*}{ Compound } & \multirow{2}{*}{$\begin{array}{c}\text { Final } \\
\text { concentration } \\
\left(\mathrm{M} \times 10^{-3}\right)\end{array}$} & \multirow{2}{*}{$\begin{array}{c}\text { No. of } \\
\text { experiments }\end{array}$} & \multicolumn{2}{|c|}{ Average inhibition index } \\
\hline & & & Bacteriophage & Bacteria \\
\hline Arsenite, $\mathbf{K}$ or $\mathbf{N a}$ & $\begin{array}{l}1 \cdot 0 \\
0 \cdot 5 \\
0 \cdot 25 \\
0 \cdot 10\end{array}$ & $\begin{array}{l}\mathbf{3} \\
\mathbf{3} \\
\mathbf{3} \\
\mathbf{2}\end{array}$ & $\begin{array}{l}0 \\
0.38(0.23-0.58) \\
0.87(0.73-1.08) \\
1.04(1.04)\end{array}$ & $\begin{array}{l}0.68(0.66-0.72) \\
0.98(0.91-1.03) \\
0.94(0.88-0.96) \\
1.01(1.00-1.01)\end{array}$ \\
\hline Borate, Na & $\begin{array}{l}5 \cdot 0 \\
4 \cdot 0 \\
3 \cdot 0 \\
2 \cdot 0 \\
1 \cdot 0 \\
0 \cdot 5 \\
0 \cdot 25\end{array}$ & $\begin{array}{l}3 \\
3 \\
4 \\
4 \\
4 \\
2 \\
1 \\
1\end{array}$ & $\begin{array}{l}0 \\
0.07(0-0.2) \\
0.24(0.09-0.33) \\
0 \cdot 60(0.49-0.84) \\
0.73(0.61-0.84) \\
0.83 \\
0.91\end{array}$ & $\begin{array}{l}0.78(0.69-0.91) \\
0.94(0.92-1.01) \\
1.06(1.02-1.12) \\
1.08(0.99-1.14) \\
1.07(1.05-1.08) \\
1.16 \\
1.21\end{array}$ \\
\hline Cyanide, $\mathbf{K}$ & $\begin{array}{l}0 \cdot 4 \\
0 \cdot 2 \\
0 \cdot 1 \\
0 \cdot 05\end{array}$ & $\begin{array}{l}\mathbf{3} \\
\mathbf{3} \\
\mathbf{3} \\
\mathbf{2}\end{array}$ & $\begin{array}{l}0 \\
0.30(0.0-0.50) \\
0.50(0.41-0.68) \\
0.81(0.76-0.85)\end{array}$ & $\begin{array}{l}0.83(0.78-0.85) \\
0.95(0.94-0.96) \\
0.99(0.92-1.05) \\
1.00(1.00)\end{array}$ \\
\hline Proflavine & $\begin{array}{l}0.01 \\
0.005 \\
0.0025 \\
0.001\end{array}$ & $\begin{array}{l}3 \\
3 \\
2 \\
2\end{array}$ & $\begin{array}{l}0 \\
0.07(0-0.21) \\
0.39(0.15-0.63) \\
0.95(0.91-0.98)\end{array}$ & $\begin{array}{l}0.90(0.85-0.95) \\
0.95(0.84-1.03) \\
1.02(0.99-1.04) \\
1.01(0.99-1.02)\end{array}$ \\
\hline
\end{tabular}

Figures in parentheses show the range in individual experiments.

Table 4. Effect of inhibitors on phage $T 2 r^{+}$alone

$\begin{array}{lc}\text { Inhibitor } & \begin{array}{c}\text { Titre of } \\ \text { phage after } \\ 4 \text { hr. at 37 } \\ \left(\times 10^{6}\right)\end{array} \\ \text { Saline control } & 44.5 \\ \text { Arsenite, } 2 \times 10^{-3} \mathrm{M} & 46.3 \\ \text { Borate, } 7 \times 10^{-3} \mathrm{M} & 41.0 \\ \text { Cyanide, } 0.8 \times 10^{-3} \mathrm{M} & 41.0 \\ \text { Proflavine, } 0.05 \times 10^{-3} \mathrm{M} & 11.1\end{array}$

Ten ml. phage, diluted in GTP broth, added to $1 \mathrm{ml}$. inhibitor in saline, to give the final concentration shown in Table. Incubated $4 \mathrm{hr}$. at $37^{\circ}$, then diluted and assayed.

washed once on the centrifuge with phosphate saline to remove free phage, and resuspended in phosphate saline at $5-10 \times 10^{7}$ bacteria $/ \mathrm{ml}$. Such suspensions, and dilutions of them in phosphate saline, were stable for at least $1 \mathrm{hr}$. at $30^{\circ}$, but developed normally on addition of nutrient medium and had a latent period of normal length $\left(28 \mathrm{~min}\right.$. at $\left.30^{\circ}\right)$. In one experiment portions of a dilute suspension in phosphate saline were added 1, 15, 30 and $60 \mathrm{~min}$. after preparation to GTP broth to give a count of $1 \cdot 1 \times 10^{3}$ plaques $/ \mathrm{ml}$. After 
$100 \mathrm{~min}$. incubation at $30^{\circ}$ the respective titres were $139,119,146$ and $134 \times 10^{3}$ plaques $/ \mathrm{ml}$. Burst sizes of over 100 were, however, unusual, the normal range being 50-100. This variation might have been due to variation in the composition of the medium and in the conditions of centrifugation and aeration. Attempts to improve reproducibility by substituting for broth the defined medium of Friedlein (1928) either alone, +0.1\% Tryptose, or + yeast extract, were unsuccessful.

(b) In later experiments a method was used which proved simpler and gave larger burst sizes. To a log phase culture of Escherichia coli strain B $\left(1 \times 10^{8}\right.$ organisms $/ \mathrm{ml}$.) in GTP broth at $37^{\circ}$ were added cyanide or arsenite to a concentration of $1 \times 10^{-3} \mathrm{M}$ and phage $\mathrm{T} 2 \mathrm{r}^{+}$to give a final concentration of $1 \times 10^{5}$ particles $/ \mathrm{ml}$., and the culture was incubated for $10 \mathrm{~min}$. at $37^{\circ}$. More than $98 \%$ of the phage was adsorbed, as measured by the supernatant titre after centrifuging, but its development was prevented by the cyanide or arsenite. On dilution into GTP broth to bring the concentration of cyanide or arsenite below its effective level the phage developed normally and gave burst sizes over 100.

Both types of suspension were added to GTP broth at $30^{\circ}$, containing different concentrations of inhibitor, to give an initial count of $10^{3}$ plaques $/ \mathrm{ml}$. and the increase in titre followed as usual in single step experiments. The lower temperature of incubation $\left(30^{\circ}\right)$ gave slower multiplication and more time for manipulation, the latent period being increased from $19 \mathrm{~min}$. at $37^{\circ}$ to $28 \mathrm{~min}$. at $30^{\circ}$.

Multiplication of Escherichia coli strain B was followed by viable count after adding a washed aerated suspension of bacteria in phosphate saline to GTP broth + inhibitor. The initial titre was $10-30 \times 10^{6}$ organisms $/ \mathrm{ml}$. The effect of inhibitors is expressed as the ratio of the uncorrected mean generation time (MGT) of the inhibited and control cultures:

$$
\frac{\text { MGT of culture }+ \text { inhibitor }}{\text { MGT of control culture }} \text {. }
$$

Arsenite. Fig. 1 shows that 0.25 and $0.5 \times 10^{-3} \mathrm{M}$-arsenite had little effect on the growth of Escherichia coli strain B their MGT ratios being 1.08 and 1.20 respectively. A higher concentration of arsenate $\left(1 \times 10^{-3} \mathrm{M}\right)$ was not inhibitory at all (MGT ratio=1.02). But the same concentrations of arsenite greatly decreased phage yield in single step experiments (Fig. 2). The yield was never more than sevenfold in the presence of $0.25 \times 10^{-3} \mathrm{M}$-arsenite and $0.5 \times 10^{-3} \mathrm{M}$-arsenite suppressed multiplication completely. Arsenite thus appears a more effective inhibitor in these experiments than in the preliminary survey, in which $0.5 \times 10^{-3} \mathrm{M}$-arsenite did not cause complete inhibition. The concentration of bacteria and phage was many thousand times higher in the early experiments and this probably explains the difference, since the number of inhibitor molecules/bacterium was higher in the single step experiments. Both methods of preparing the phage + bacteria suspensions gave similar results.

Cyanide at 0.2 and $0.4 \times 10^{-3} \mathrm{M}$ had effects similar to those of arsenite 


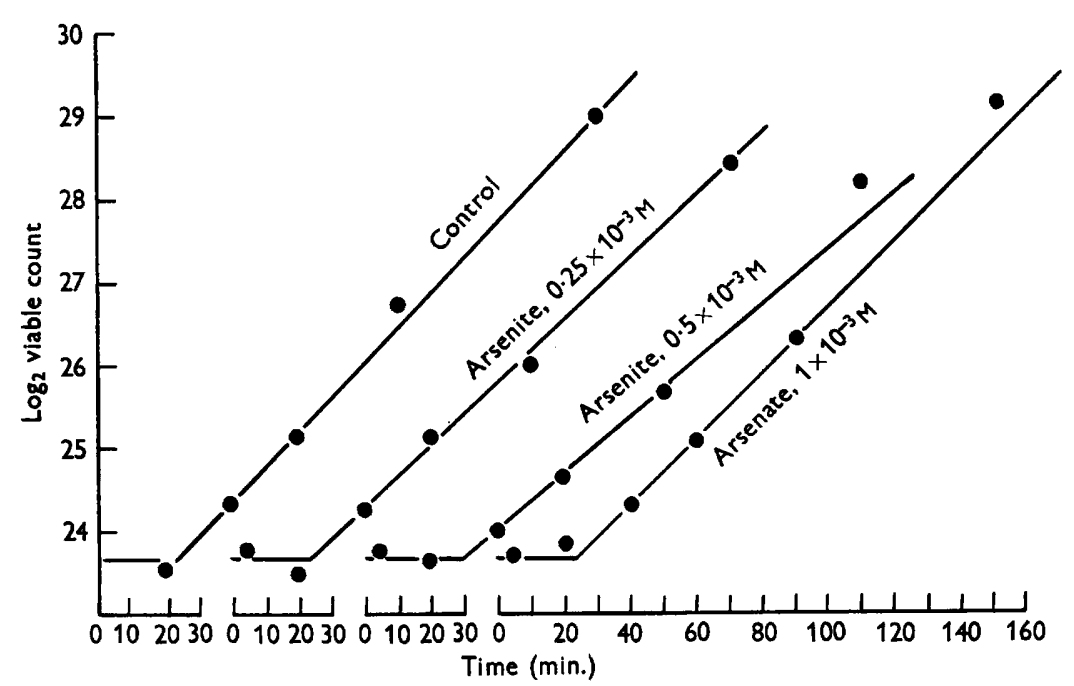

Fig. 1. Effect of arsenite and arsenate on growth of Escherichia coli strain B measured by viable count. Initial titre: $13 \times 10^{8}$ viable organisms $/ \mathrm{ml} .3^{\circ}$.

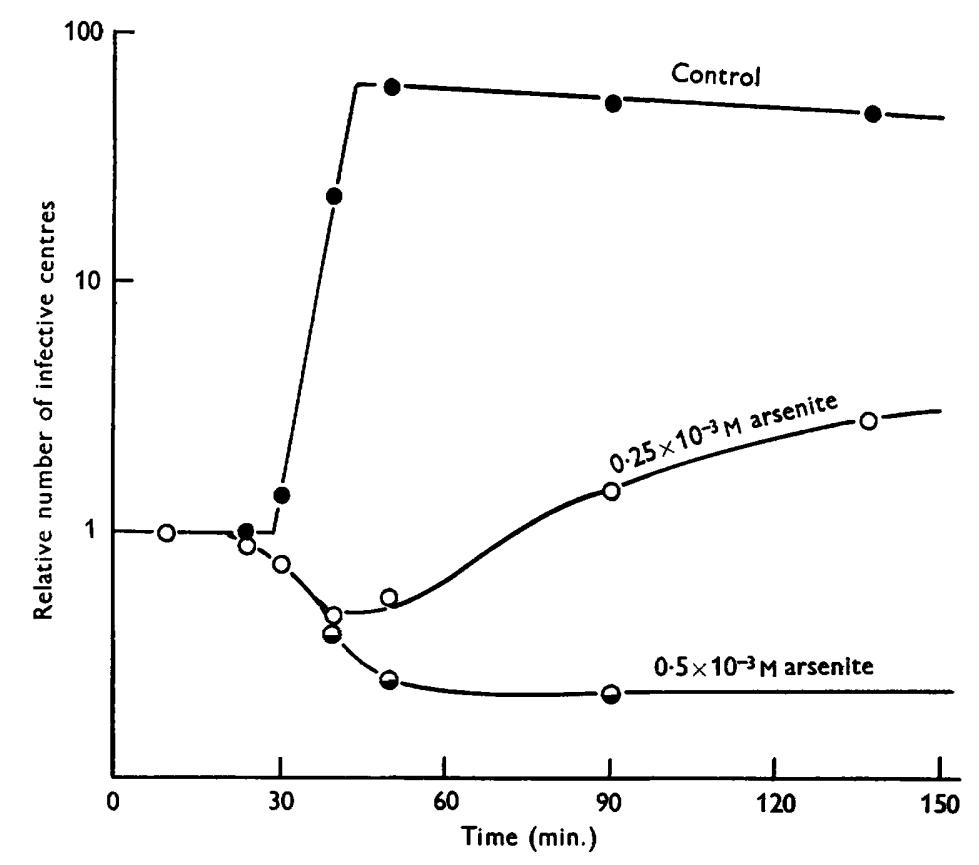

Fig. 2. Effect of arsenite on growth of phage $\mathrm{T} 2 \mathrm{r}^{+}$in single step experiment. $30^{\circ}$. 
(Figs. 3, 4). Doermann (1952) has already shown that at the higher concentration of cyanide $(0.01 \mathrm{M})$ used in his method for studying intracellular phage, there is a loss of infectious centres during the first half of the latent period but the bacteria are not lysed by the cyanide; lysis occurs only when the cyanide is added near the end of the latent period. Cyanide thus has two separate effects, inhibition of phage multiplication when it is added early in

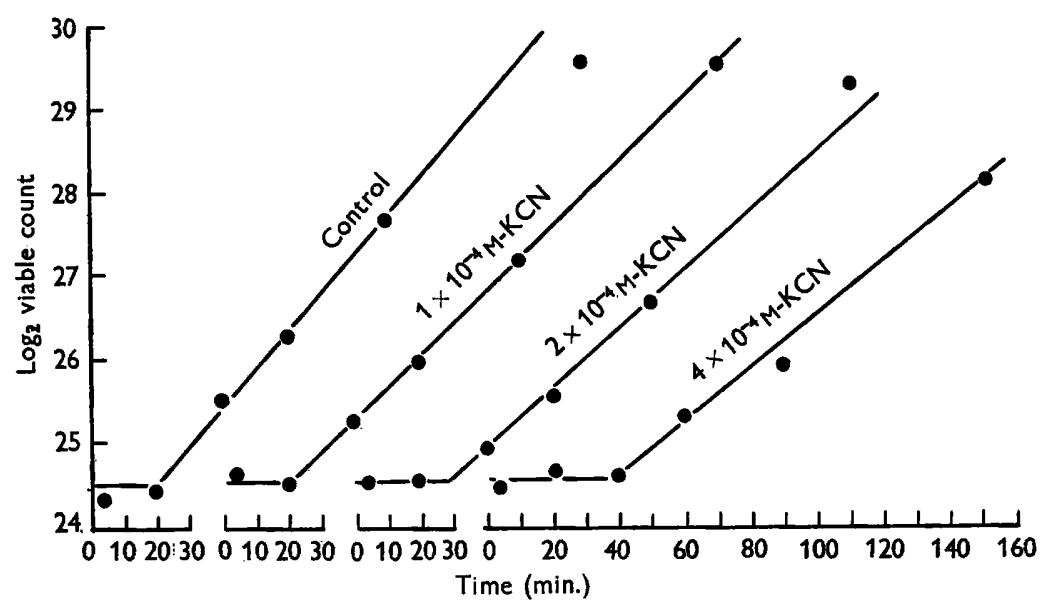

Fig. 3. Effect of cyanide on growth of Escherichia coli strain B, measured by viable count. Initial titre: $24 \times 10^{6}$ viable organisms $/ \mathrm{ml}$. $37^{\circ}$.

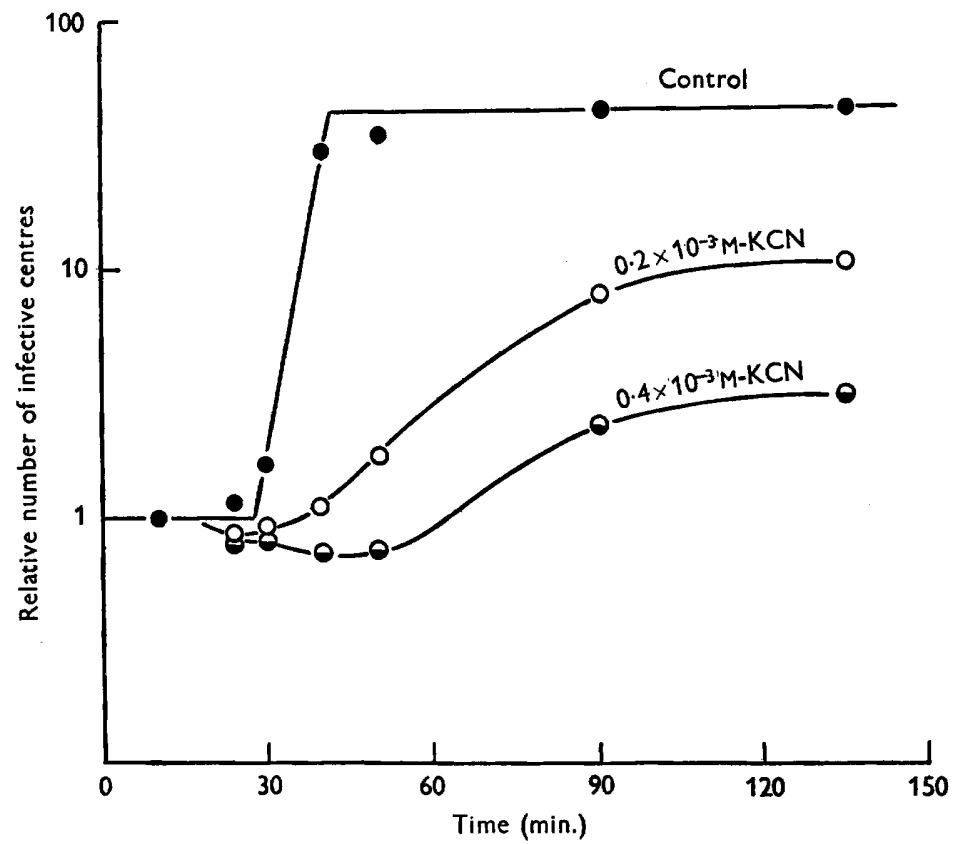

Fig. 4. Effect of cyanide on growth of phage $\mathrm{T} 2 \mathrm{r}^{+}$in single step experiment. $30^{\circ}$. 
the latent period, and lysis when it is added after some intracellular phage particles are completed. Only the inhibitory effect has been studied in the present experiments.

Borate at 2, 4 and $8 \times 10^{-3} \mathrm{M}$ gave average MGT ratios for growth of the bacteria of 1.04, 1.08 and 1.14 respectively, with no increase in the length of the lag phase. Experiments in which the phage + bacteria suspension was prepared by washing and aeration of the bacteria gave no evidence that these concentrations of borate inhibited phage development; single step growth curves with and without inhibitor were identical. But when the suspensions

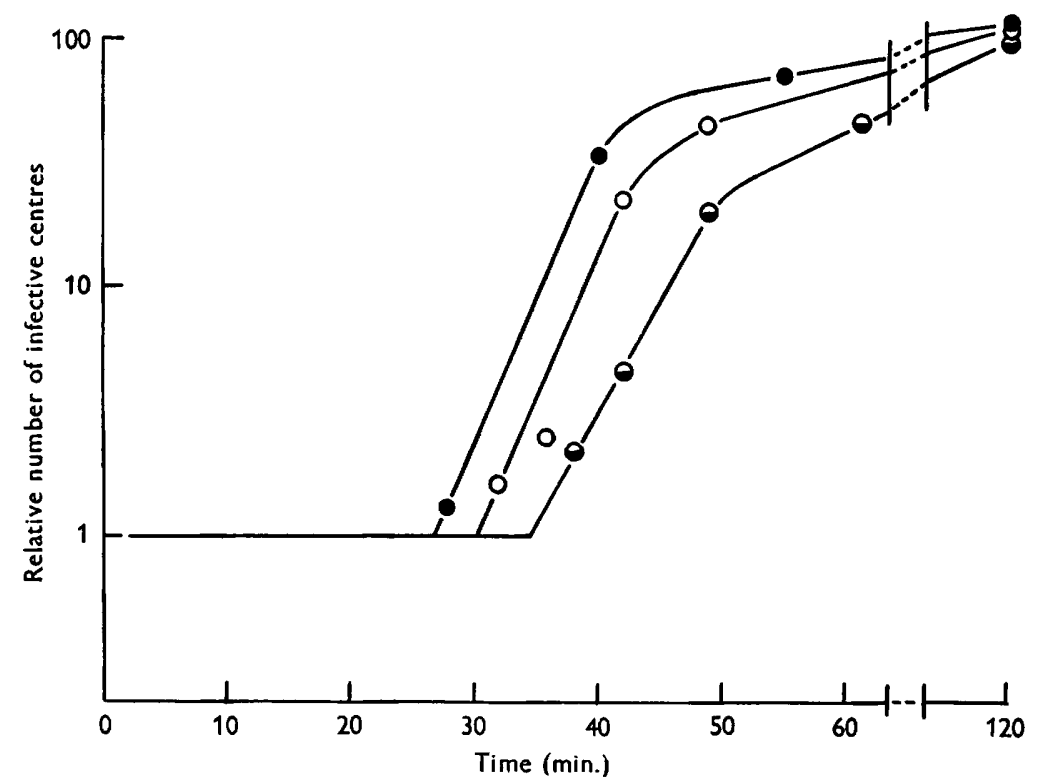

Fig. 5. Multiplication of phage $\mathbf{T} 2 \mathrm{r}^{+}$in single step experiment in presence of borate. Suspension of phage + bacteria, arrested by $1 \times 10^{-3} \mathrm{M}$-cyanide, diluted $1 / 100$ into GTP broth + borate. $30^{\circ}$. -0 , Control; $0-0,4 \times 10^{-3} \mathrm{M}$-borate; $\theta-\theta, 8 \times 10^{-3} \mathrm{M}$ borate.

of phage + bacteria whose development had been arrested by cyanide or arsenite were diluted into GTP broth containing borate inhibition did occur. The latent period was increased from $28 \mathrm{~min}$. to $30-31 \mathrm{~min}$. by $2 \times 10^{-3} \mathrm{M}-$ borate, to $31-33 \mathrm{~min}$. by $4 \times 10^{-3} \mathrm{M}$, and to $36 \mathrm{~min}$. by $8 \times 10^{-3} \mathrm{M}$, but the final titres were almost identical with that of the control, though some decrease occurred in a few experiments. When a suspension of phage + bacteria inhibited by cyanide was centrifuged down, resuspended in fresh GTP broth + cyanide, and then diluted into GTP broth + borate, the usual increase in latent period did not take place. The process of centrifugation and resuspension had evidently annulled the inhibition. This provides an explanation for the fact that suspensions of phage + bacteria prepared by washing and aeration were not inhibited by borate. The results of these experiments justify the assumption made earlier (see SCREENING TESTS) that the length of the latent period might prove a more sensitive indicator of inhibition than decrease in final titre. 


\section{Effect of time of addition of inhibitor on phage production}

In experiments to determine how late in the latent period the addition of inhibitors remained effective, washed suspensions of phage + bacteria in phosphate saline were added as usual to GTP broth to start phage multiplication; further dilutions were made at intervals into broth + inhibitor at $30^{\circ}$, to give $1-3 \times 10^{3}$ plaques $/ \mathrm{ml}$. and the single step growth curve followed. Inhibition by arsenite occurred when the dilution into arsenite was made as late as $\mathbf{1 5}$ min. after the beginning of the latent period (Fig. 6), and other experiments showed complete inhibition when the dilution was made at $15 \mathrm{~min}$. and partial inhibition even when it was made at 22 min. Results with cyanide were similar, although the inhibition at $10 \mathrm{~min}$. was less complete and there was none at $20 \mathrm{~min}$., a result to be expected from the experience of Doermann (1952) in his cyanide lysis experiments.

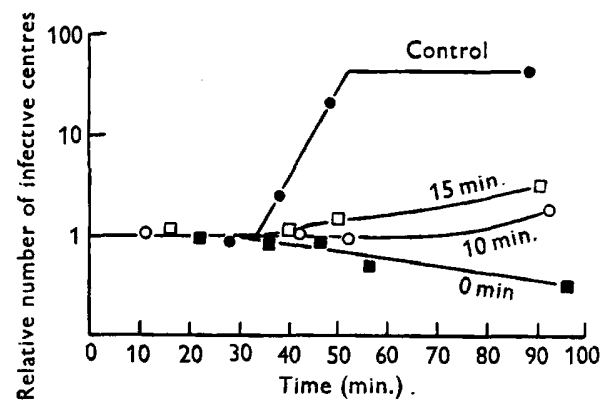

Fig. 6

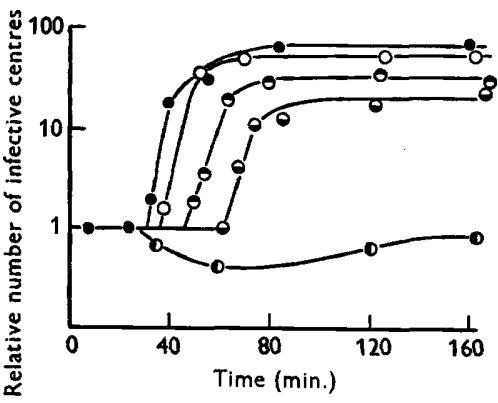

Fig. 7

Fig. 6. Effect of addition of $1 \times 10^{-3} \mathrm{M}$-arsenite at different times during latent period to phage $\mathbf{T} 2 \mathrm{r}^{+}$in single step experiment. $30^{\circ}$.

Fig. 7. Effect of removal of $0.5 \times 10^{-3} \mathrm{M}$-arsenite at different times during latent period of phage $\mathrm{T}_{2} \mathrm{r}^{+}$in single step experiment. $30^{\circ}$. -0 , Control without arsenite; $\mathrm{O}-\mathrm{O}$, arsenite $0-10 \mathrm{~min}$; $\theta-\theta$, arsenite $0-20 \mathrm{~min}$; $\theta-\theta$, arsenite $0-30 \mathrm{~min}$; $0-0$ arsenite present throughout.

When arsenite present at the beginning of the experiment was diluted out at different times during the latent period, its effect was to delay the end of the latent period by approximately the time the inhibitor had been present (Fig. 7). In this it resembles most other phage inhibitors.

\section{DISCUSSION}

The results described in this paper show that an examination of the effect of enzyme inhibitors on phage multiplication will readily reveal some which inhibit phage differentially. Spizizen (1943) made a similar approach by testing the effect of a number of enzyme inhibitors on the multiplication of washed cells of Escherichia coli strain $\mathrm{B}_{1}+$ phage $\mathrm{P}_{1}$ in phosphate buffer + glycine anhydride $\left(0.87 \times 10^{-3} \mathrm{M}\right)$ or in broth, finding complete inhibition by $\mathrm{NaCN}\left(2 \times 10^{-3} \mathrm{M}\right)$, monoiodoacetic acid $\left(0.5 \times 10^{-3} \mathrm{M}\right)$, sodium arsenite $\left(0.6 \times 10^{-3} \mathrm{M}\right), 2$ :4-dinitrophenol $\left(0.5 \times 10^{-3} \mathrm{M}\right)$ or $p$-amino-phenol 
$\left(1 \times 10^{-3} M\right)$. Spizizen's conditions, however, differed from those in the present work since the bacteria were unable to multiply in the glycine anhydride, and he did not test the growth of the bacteria in broth which contained the same concentration of inhibitor. The present experiments did not reveal any differential effects of monoiodoacetic acid or 2:4-dinitrophenol, but did confirm those of cyanide and arsenite. The ratio concentration of inhibitor required to suppress growth of phage to concentration required to inhibit bacteria is not as great with arsenite, borate and cyanide as with some other inhibitors, but the effect was clear and reproducible.

Arsenite and cyanide inhibit respiratory and fermentative processes, arsenite by combining with SH-containing enzymes and cyanide by forming complexes with heavy metals. Escherichia coli strain B possesses two routes of carbohydrate breakdown, the normal fermentative one and an oxidative pathway via phosphogluconic acid and pentose phosphates. The two are in an equilibrium which may be altered by varying conditions, so that inhibition of one by cyanide or arsenite leads to increased use of the other pathway and a decrease in the effect of the inhibitor. When the cells are infected with coliphage $\mathrm{T}_{2} \mathrm{r}^{+}$, however, there is a shift in glucose metabolism from the oxidative to the anaerobic pathway (Cohen, 1951; Cohen \& Roth, 1953), and the simplest explanation of the present results is that the equilibrium is disrupted by phage infection and that arsenite and cyanide inhibit the anaerobic pathway specifically.

Borate was tested for inhibitory activity because it is known to combine with ribose-5-phosphate and ribulose-5-phosphate, both products of the oxidative respiratory pathway of Escherichia coli (Horecker, Smyrniotis \& Seegmiller, 1951). It is clear that its mode of action differs from that of cyanide and arsenite. Since the change from the oxidative to the anaerobic pathway referred to above occurs after infection with phage, borate should be effective as an inhibitor only so long as the oxidative pathway is still in use and it should not alter the phage yield. The lengthened latent period and unchanged phage yield found are thus consistent with the hypothesis that borate acts on pentose phosphate.

It is a pleasure to acknowledge a gift of sodium fluoroacetate from Professor Sir Rudolf Peters.

\section{REFERENCES}

BENzER, S. (1952). Resistance to ultraviolet light as an index to the reproduction of bacteriophage. J. Bact. 63, 59.

CoHen, S. S. (1951). Utilization of gluconate and glucose in growing and virusinfected Escherichia coli. Nature, Lond. 168, 746.

Conen, S. S. \& Rotн, L. (1953). The phosphogluconate pathway of carbohydrate metabolism in the multiplication of bacterial viruses. J. Bact. 65, 490.

Czekalowski, J. W. \& Dolby, D. E. (1949). Effect of enzyme inhibitors on the genesis of phage. Nature, Lond. 163, 719.

DoermanN, A. H. (1952). The intracellular growth of bacteriophages. I. Liberation of intracellular bacteriophage $\mathbf{T} 4$ by premature lysis with another phage or with cyanide. J. gen. Physiol. 35, 645 . 
Foster, R. A. C. (1948). An analysis of the action of proflavine on bacteriophage growth. J. Bact. 56, 795.

Friedlein, F. (1928). Der quantitative Verwendungsstoffwechsel des ParatyphusB-Bazillus, des Bacterium coli und des Bacillus pyocyaneus. Biochem. Z. 194, 273.

HedÉn, C.-G. (1951). Studies of the infection of $E$. coli B with the bacteriophage T2. Acta path. microbiol. scand. Supplementum 88.

Herriotr, R. M. \& Barlow, J. L. (1952). Preparation, purification and properties of E. coli virus T2. J. gen. Physiol. 36, 17.

Hershey, A. D., Kalmanson, G. M. \& Bronfenbrenner, J. (1943). Quantitative methods in the study of the phage-antiphage reaction. J. Immunol. 46, 267.

Horecker, B. L., Smyrniotis, P. Z. \& Seegmiller, J. E. (1951). The enzymatic conversion of 6-phosphogluconate to ribulose-5-phosphate and ribose-5-phosphate. J. biol. Chem. 193, 383.

ScotT, D. B. MACN. \& CoHEN, S. S. (1953a). The oxidative pathway of carbohydrate metabolism in Escherichia coli. 1. The isolation and properties of glucose-6phosphate dehydrogenase and 6-phosphogluconate dehydrogenase. Biochem. J. $55,23$.

ScotT, D. B. MacN. \& Cohen, S. S. (1953b). The oxidative pathway of carbohydrate metabolism in Escherichia coli. 2. Quantitative studies of glucose-6phosphate dehydrogenase and 6-phosphogluconate dehydrogenase. Biochem. J. $55,33$.

SpIzizen, J. (1943). Biochemical studies on the phenomenon of virus reproduction. II. Studies on the influence of compounds of metabolic significance on the multiplication of bacteriophage. J. infect. Dis. 73, 222.

Swanstrom, M. \& Adams, M. H. (1951). Agar layer method for production of high titre phage stocks. Proc. Soc. exp. Biol., N.Y. 78, 372. 